Portland State University

PDXScholar

1975

\title{
An Identification of Important Management, Administrative, and Planning Skills and Knowledge Essential to Middle-managers Present Positions in a Variety of Urban and Rural Social Welfare Settings in Oregon
}

Patricia Victoria Leonard Portland State University

Follow this and additional works at: https://pdxscholar.library.pdx.edu/open_access_etds

Part of the Social Work Commons

Let us know how access to this document benefits you.

\section{Recommended Citation}

Leonard, Patricia Victoria, "An Identification of Important Management, Administrative, and Planning Skills and Knowledge Essential to Middle-managers Present Positions in a Variety of Urban and Rural Social Welfare Settings in Oregon" (1975). Dissertations and Theses. Paper 1825.

https://doi.org/10.15760/etd.1824

This Thesis is brought to you for free and open access. It has been accepted for inclusion in Dissertations and Theses by an authorized administrator of PDXScholar. Please contact us if we can make this document more accessible: pdxscholar@pdx.edu. 
AN IDENTIFICATION OF IMPORTANT MANAGEMENT, ADMINISTRATIVE, AND PLANNING SKIILS AND KNOWIKDGE ESSENTIAL TO MUDDLE-MANAGERS PRESENT POSITIONS IN A VARIETY OF URBAN AND RURAL SOCIAI WELFARE SETTINGS IN OREGON

by

PATRICIA VICTORIA IEONARD

1 researah practicun submitted in partial fulfillmont of the requirements for the degree of

MASTER OF SOCIAL WORK

Portland State University

1975 
TO THE CFFICE OF GRADUATE STUDIES:

The Advisors Approve The Report of:

PATRICIA VICTCRIA LEONARD

Presented June 10, 1975.

Gerald A. Frey

CIInda A. Kaeser 


\section{ACKNOWLEDGEMENTS}

Sincere appreciation is extended to Gerald Frey, my advisor and project director, and to Linda Kaeser, the project planner. They assisted me in the preparation of this study, and the many readings of rough drafts. Without their advice and encouragement I would not have successfully completed this study.

I would also like to thank Nancy Koroloff for her assistance in the design of the research. I am furthermore grateful to to the people who agreed to participate in this study. As a result of their cooperation this study was possible.

Special thanks are extended to Betsie DeBeer smith for her wisdom and guidance, and for her help in editing the entire study. 
TABLE OF CONTENTS

PAGE

ACKNOWLEDGEMENTS . . . . . . . . . . . . . . . . . iii

IIST OF TABLES . . . . . . . . . . . . . . . . . . vi

CHAPTER

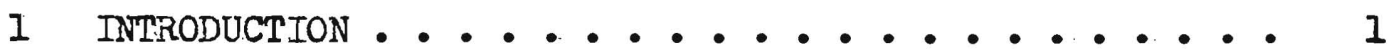

Geographic Distribution ............ 2

Method and Scope of Study ............ 2

17 ACADEMTC EDUCATION OF THE MANAGERS . . . . . . . . 5

Additional Education and Training ......... 5

111 EXPERTENCE OF THE MANAGERS . . . . . . . . 8

V1 PERSONAL TRATTS AND BREADTH AND DEPTH OF KNOWLEDGE • • 10

V. THE FUNCTIONING OF MANAGERS IN RELATION TO TIME SPENT • 14

External Forces ............ 14

Program Management ............. 15

Financial Management .............. 16

Personnel Management .............. 17

VI ESSENTIAL KNOWLEDGE, PERSONAL ATTRIBUTES AND SKIILIS •... 20

Experience ................. 21

Personal Attributes ...... . . . . . 22

Communication Skills . . . . . . . . . 23

General Knowledge ............. 24 
Change Agent Skills . . . . . . . . 25

Management Skills . . . . . . . . . 26

VII SUMMARY STATEMENT OF ESSENTIAL ITEMS AND ATTRIBUTES. 29

The Ideal Manager .......... 30

VII IMPLICATIONS FOR EDUCATION OF POTENTIAL MANAGERS • • 31

Curriculum . . . . . . . . . . 31

Field Placement ........... 34

Continuing Education ......... 35

BIBLTOGRAPHY . . . . . . . . . . . . . . 36

APPENDIX . . . . . . . . . . . . . . . . 37 


\section{LIST OF TABLES}

TABLE

PAGE

1 Number of Staff and Number of Managers Within Each

County ................... 3

11 Nultnomah County-Specific Education and Training . . . . 5

111 Melhour County- Spocific Education and Training . . . . 5

IV Jackson County- Specific Education and Training . . . . 6

V Throe County Total- Spocific Education and Training . . 6

V1 Months in Present-Position . . . . . . . . . 8

VIl Years in Human Service Field . . . . . . . . . 8

VIl Years in Planning or Management . . . . . . . . . 9

IX Personal Traits and Characteristics and Breadth and Depth of

Knowledge- Multnomah County ............ 10

X Personal Traits and Characteristics and Breadth and Depth of Knowledge- Melhour County ............. II

XI Porsonal Traits and Characteristics and Breadth and Depth

of Knorledge- Jackson County ............ 12

XI1 Percent of Time Spent on External Forces . . . . . . 14

XII Rank of Amount of Time Spent on Extermal Forces . . . . 14

XIV Percent of Time Spent on Program Management . . . . . 15

XV Rank of Amount of Time Spent on Program Management . . . 16

XV1 Percent of Time Spent on Financial Management . . . . 17

XVIl Rank Time Spent on Financial Kanagement . . . . . . 17

XVIII Percent of Tume Spent in Personnel Management . . . . 18 
TABLE

PAGE

XIX Rank Time Spent in Personnel Management ........ 18

XX Type of Experience Considered Essential to Manager's

Present Positions .............. 21

$\therefore \mathrm{XX}$ Personal Attributes Considered to be Essential to

Manager's Present Positions . . . . . . . 22

XXI1 Communication Skills Considered to be Essential to Manager's Present Positions ............ 23

XXI1I General Knowledge Areas Considered to be Essential by Managers .................. 24

XXIV Change Agent Skills Considered to be Essential by

Managers ................ 25

XXV Management Skills Considered to be Essential by

Managers ................ 26 


\section{CHAPTER 1}

\section{INTRODUCTION}

In July, 1974 the Social Rehabilitation Services of the Department of Health, Education and Welfare, awarded a grant to the School of Social Work at Portland State University to "identify and examine the skills and abilities that are utilized by middle-management personnel in the human 1

services field." The project sought to (1) identify and prioritize the management, administrative and planning skills utilized by practitioners in a variety of urban and rural soctal welfare setting throughout Oregon, (2) develop a list of middle-management skills deemed important for graduate and undergraduate students in the School of Social Work, and (3) provide data upon which to redesign a curriculum for the development of management and planning skills. In essence, the project sought data to strengthen cirricule in management and planning areas and link graduate and undergraduate education more closely with community prectice.

As an initial step in the project, 22 open onded interviews were held with chief executives in public agencies in the state of oregon. Chief executives included directors, deputy assistants and directors: of major departmental divisions. Functional fields included mentel health, services to children and families, and adult and juvenile: corrections.

1

The title of the project was "Performance Education in Nianagement." 2

Frey, Gerald A. and Iinda Kaeser. "What do Human Service Executives Bay They Want In Their Program Managers?" Unpublished, 1975. 
All of the executive personnel were related to the State of Oregon's Department of Human Resources, Multnomah County's Department of Human Services, and the City of Portland's Bureau of Human Resources. The purpose of interviewing these individuals was three-fold. The first was to obtain their permission to interview some of their program managers: the second to elicit their views regarding the skills and knowledge areas they believed were important to program managers; and the third was to design an interview schedule based upon the results of the open ended interviews. Executives were also questioned about what skills and knowledge they looked for when hiring a manager. The responses of the executives were arranged into general categories identifying education and training, skill and experience, time expenditure and personal characteristics. This information was consequently usied to design an interview schedule. The interview attempted to identify the important management, administrative and planning skills and knowledge essential to middle-managers in a variety of urban and rural social welfare settings in Oregon.

Goographic Distribution

Individuals from three different aress of the stitesweresselected to be interviewed. These areas were Multnomah, Malhour and Jackson Counties. Respectively, they represent the state's northern-urban, eastern-rural, and southerm-rural populations. Mothod and Scope of the Study

People in managewent and staff positions were selected by the planner of the project through a purposive sampling technique. All of these persons were related to social services provided by Oregon 
Department of Human Resources, Multnomah County, the City of Portland, Malheur County, including the cities of Ontario and Nyssa, and Jackson County, including the cities of Medford and Ashland. This study is part of a larger study and does not include state level employees. In other words, the focus of this study is upon those persons employed by their County or City government. A study of the state employees is a project boing undertaken separately. Initially, all prospective interviewees were contacted by a letter from the project planner. This letter included general information about the purpose of the study and invited the prospective interviewees to participate in the study by allowing themselves to be interviewed for approximately one hour. Personal interviews were held with each manager.- The largest part of the schedule used for the interview consisted of closed questions; however, a few openended questions were included at the end (see Appendix A).

Within Multnomah. Malheur and Jackson County a total of 26 managers and three staff persons were interviewed.

\section{TABLE 1}

NUMBER OF STAFF AND NUMRER OF MANAGERS WITH IN EACH COUNTY

$$
\text { MANAGERS } \text { STAFF }^{3}
$$

Multnomah

Melheur Jackson

$\begin{array}{rr}15 & 2 \\ 5 & 1 \\ 6 & 0\end{array}$

A review of the available data showed that the respondents worked in a variety of setting, such as mental health, services to children and families, and adult and juvenile corrections. 
Of the 29 respondents, 22 held bachelor's degrees in the area of social service or social science. A further review of the data shows that II of those persons went on to obtain master's degrees, and three received doctoral degrees. In addition, only three persons had master's degrees in social work, the remaining eight being in a variety of areas. The average length of time since the respondents received their undergraduate degrees was similar in all three counties, about $8 \frac{1}{2}$ years. This similarity also held true for the length of time since they received their last graduate degre日, about $3 \frac{1}{2}$ years. 
ACADEMIC EDUCATION OF THE MANAGERS

Almost 271 of the managers and staff persons interviewed had taken additional training institutes or workshops. In Nultnomah County over four-fifths of the respondents had taken additional training in interviewing techniques, systems theory, organizational theory and management by objectives. Twelve people had additional training in problem solving techniques and planning theory and techniques.

TABLE II

MULTNOMAH COUNTY - SPECIFIC EDUCATION AND TRAINING

\begin{tabular}{lcc}
\multicolumn{1}{c}{ Category } & Frequency & $\frac{\text { Percent }}{14}$ \\
Interviewing Techniques & 14 & 82 \\
Systems Theory & 14 & 82 \\
Organizational Theory & 14 & 82 \\
Management by Objectives & 12 & 70 \\
Problem Solving Techniques & 12 & 70 \\
Planning Theory/Techniques & 12 &
\end{tabular}

Reviewing Table III, we find that in Melhour Connty five out of six poople interviewed had taken additional training institutes or workshops in management theory, interviewing techniques, problem solving techniques and personnel management.

TABLE III

MAIHEUR COUNTY - SPECIFIC EDUCATION AND TRAINING

Mansgement Theory

Interviering Techniques

Problem Solving Techniques

Personnel Management

\begin{tabular}{cc} 
Frequency & Percent \\
\cline { 1 - 1 } 5 & 83 \\
5 & 83 \\
5 & 83 \\
5 & 83
\end{tabular}


As Table IV shows, in Jackson County five out of six respondents had additional training in task group dynamics and the legislative process.

TABLE IV

JACKSON COUNTY - SPECIFIC EDUCATION AND TRAINTNG

\begin{tabular}{lcc}
\multicolumn{1}{c}{ Category } & Frequency & Percent \\
\cline { 2 - 3 } Legislative Process & 5 & 83 \\
Task Group Dynamics & 5 & 83 \\
Community Development & 4 & 66 \\
Data Systems & 4 & 66 \\
Public Presentation & 4 & 66 \\
Problem Solving Techniques & 4 & 66 \\
Management by Objectives & 4 & 66
\end{tabular}

Laoking at Table V, we find that in the three counties a number of items referring to additional oducation and training appear to be significant. For example, over one-half of the managers have had additional training in the general category of communication skills, which includes interviewing techniques, tesk group dynamics and public presentation. Also, over half, or 53\%, have had training in community development. In addition, over half of the managers had taken advantage of training in management theory and management by objectives.

TABLE V

THREE COUNTY TOTAL - SPECIFIC EDUCATION AND TRAINING

Category

Problem Solving Techniques

Interviewing Techniques

Management by Objectives

Logislative Process

Organizational Thoory

Community Development

Task Group Dymamics

Management Theory

Problem Analysis

Public Presentation

Planning Theory/Techniques

\begin{tabular}{cc} 
Frequency & Percent \\
\cline { 1 - 2 } 21 & 73 \\
22 & 72 \\
21 & 66 \\
18 & 64 \\
20 & 61 \\
17 & 58 \\
16 & 56 \\
19 & 55 \\
16 & 53 \\
16 & 52 \\
17 & 51
\end{tabular}


In summary, a review of the data indicates that almost threefour ths of the interviowees had additional training in problem solving techniques, and over half in problem analysis. This data might suggest an emphesis on problem-focused menagement on the pert of the persons interriewed in this study. Additionally, organizational theory and planning theory and techniques had been studied by over half of the respondents. 
The average length of time the respondents spent in their present positions varied considerably between Multnomah County and the two rural counties.

\section{TABIE VI}

MONTHS IN PRESENT POSITION

$\begin{array}{llll} & & \text { Mean } & \frac{\text { Range }}{3-48} \\ \text { Multmonah } & (N=17) & \frac{14.0}{147} & 7-48 \\ \text { Malheur } & (N=6) & 30.8 & 1-120 \\ \text { Jackson } & (N=6) & 37.2 & 1-120 \\ \text { Total } & (N=29) & 22.0 & 1-0\end{array}$

Table VI indicates a comparatively shorter length of time spent by Multnomah County managers in their present positions than was spent by managers in the two rural counties. Part of the reason for this shorter time in Multnomah County is because of extensive reorganization within the County and the City of Portland's Bureau of Human Resources. Also, it must be taken into account that those rural counties have fowrer positions within the sociel service sector, and therefore, job mobility i. greatly reduced.

The average number of years of experience within the human service field remained about the ame within all threo counties, approximately nine years.

\section{TABLE VII}

YEARS OF EXPERIENCE IN THE HUMAN SERVICE FIELD OF RESPONDENTS

$\begin{array}{llll}\text { Multnomah } & (N=17) & \frac{\text { Moan }}{9.6} & \frac{\text { Range }}{0-20} \\ \text { Malhevr } & (N=6) & 7.2 & 2-14 \\ \text { Jackson } & (N=6) & 8.9 & 0-20\end{array}$


The average number of yoars in planning and managoment was remarkably consistent in both Multnomah and Jackson County. On the one hand, the average in Malhour County was considerably higher, since two interviewees out of the six had been in the human service field for 21 and 22 years respoctively.

\section{TABLE VIII}

YEARS IN PLANNTING OR MANAGEMENT

$\begin{array}{llrr} & & \text { Mean } & \frac{\text { Range }}{2-18} \\ \text { Multnomah } & (\mathrm{N}=17) & \frac{6.3}{2-22} \\ \text { Malheur } & (\mathrm{N}=6) & 11.7 & 2-2 \\ \text { Jackson } & (\mathrm{N}=6) & 6.3 & 2-12 \\ \text { Total } & (\mathrm{n}=29) & 7.4 & 2-22\end{array}$

The existing data suggests the following profile of middlemanagers and staff persons interviewed in Multnomah, Malheur and Jackson Counties. The information gathered indicated that these people have worked in a variety of settings, including mentel heilth, services to children and families, and adult and juvenile-corrections. One-fourth of the interviewees held no bechelor's degre日s and one-half held master's degrees. - Interestingly, almost all interviewees had additional education or training in the areas of organizational theory and planning theory and techniques, and in problem solving and problem analysis techniques. - In addition, Multnomah County respondents had spent considerably less time in their present positions then the intervierrees in the two rural counties. This can be accounted for by extensive reorganiration within the County and the City's Bureav of Human Resources. And lastly, the average number of years of experience within the human service field was nine years, and the average number of years in the area of planning and management was $7 \frac{1}{2}$ years. 
CHAPTER IV

\section{PERSONAL TRAITS AND BREADTH AND}

DEPTH OF KNOWLEDGE

To secure some perspective of the manager's view of the relative importance of personal traits and characteristics and breadth and depth of knowledge, the respondents were asked to rank five variables. The five variables were: (1) personal traits and characteristics, (2) broad based knowledge of management, (3) broad based knowledge of the human service field, (4) in-depth knowledge of management, and (5) an in-depth knowledge of the human service field. In addition. they were asked to rank the five variables separately for managers and for staff positions. This method of ranking made it possible to begin to view similarities and differences between counties and the relative importance of the items.

TABLE IX

PERSONAL TRAITS AND CHARACTERISTICS AND BREADTH AND DEPTH OF KNOWLEDGE (Relative Importance I=highest - 5=lowest)

\section{MULTNOMAH COUNTY}

\section{Variable}

Personal Traits \& Characteristics

Broad Based Knowledge of Management

Broad Based Knowledge of Human Service Field

In-depth Knowledge of Specific Human Service Field

In-depth Knowledge of Management
Rank mean for Managers

$$
2.29
$$

2.41

2.76

3.17

4.06
Rank moan for Staff 
In Multnomah County middle-management personnel tend to rank

porsonal attributes as important for both management and staff positions. This is in addition to a broad-based knowledge of management for management positions and an in-depth knowledge of a specific human service field for staff positions.

In Malheur County a broad-based knowledge of the human services field ranked first for both managers and staff.

TABLE $X$

PERSONAI TRAITS AND CHARACTERISTICS AND BREADTH AND DEPTH OF KNOWLEDGE (Relative Importance l=highest -5 lowest)

MALHEUR COUNTY

$\underline{\text { Variable }}$

Broad Based Knowledge of Human Service Field

Broad Based Knowledge of Management

Personal Traits and

Characteristics

In-depth Knowledge

of Management

In-depth Knowledge of a Specific Human Service Field
Rank Hean for Managers

2.33

2.66

3.00

3.80
Rank Mean for Staff

$$
2.33
$$

2.66

3.40

3.00

It is interesting to note that in Malheur County the two specialist categories, i.e., in-depth knowledge of management and in-depth knowledge of a specific human service field, were ranked last for managers. In-depth knowledge of management was ranked last for staff. This is what one might expect, since staff persons rarely perform management functions. 
Finally, in Jackson County, porsonal traits and characteristics and a broad based knowledge of the human service field ranked first and second for both manager and staff.

TABLE XI

PERSONAL TRAITS AND CHARACTERISTICS AND BREADTH AND DEPTH OF KNOWLEDGE (Relative Importance l=highest $-5=$ lowest) JACKSON COUNTY

Variable

Personal Traits and Characteristics

Broad Based Knowledge of Human Service Field

Broad Based Knowledge of Management

In-depth Knowledge of Specific Human Service Field

In-depth Knowledge of Management
Rank Mean For Managers

$$
2.0
$$$$
2.16
$$

4.83
Rank Mean for Staff

2.0

2.5

3.5

3.83

3.16

In Jackson County, personal traits and characteristics appear important for both managers and staff, along with a breadth of knowledge of human services. Specific knowledge of management of human service programs was least valued by the Jackson County respondents.

Finally, looking at the three counties, respondents seem to place little emphasis on in-depth knowledge, both in the ares of management and the human service field, for both managers and staff. The one exception was Multnomah County which placed high value on an in depth 
knowledge of a specific human service field for staff. The rural counties appear to value highly broad based knowledge of the human service field and personal traits and characteristics, both for managers and staff. 
CHAPTER V

THE FUNCTIONING OF MANAGERS IN RELATION TO TIME SPENT

Four items in the questionnaire were intended to secure data regarding the amount of time spent in different aspects of work. The managers were asked what percent of their time was spent on program management, financial management, personnel management and external forces. They were also asked to rank specific elements within the four general categories of program mangement, financial management, personnel management and external forces.

TABLE XII

PERCENT OF TIME SPENT ON EXTERNAL FORCES

$\begin{array}{lll} & \text { Range } & \text { Mean } \\ \text { Multnomah } & \frac{3-55}{24.2} \\ \text { Malheur } & 15-50 & 35.8 \\ \text { Jackson } & 10-70 & 37.0\end{array}$

TABLE XIII

RANK OF AMOUNT OF TTME SPENT ON EXTEERNAL FORCES

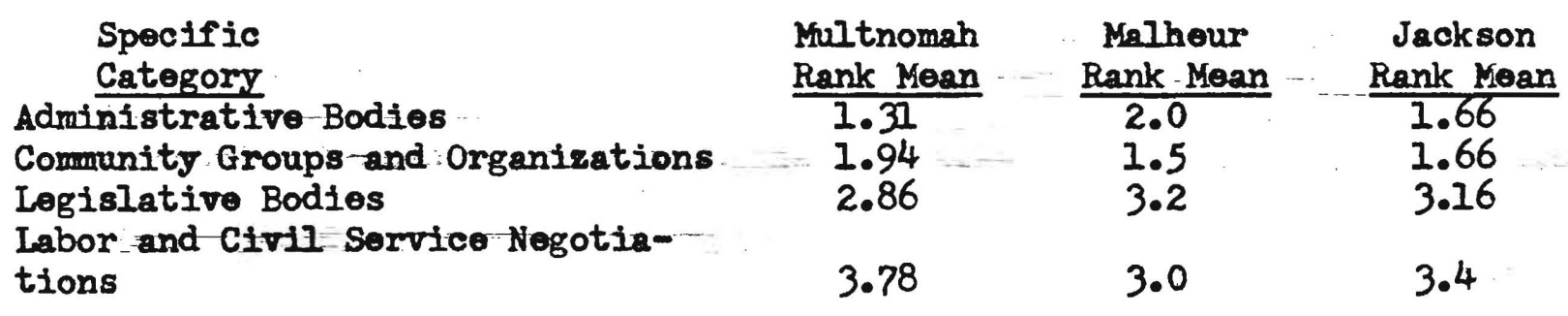

Bxternal Forces

Looking at Table XII it appears that the murel county respondents spend-considerably more time dealing-with external forces than do the 
respondents from Nultnomah County. This might be attributed to the lack of staff personnol in rural counties to carry out community organization activities, in addition to the fact that comminity interaction is of great importance in a small county.

The data in Table XIII Suggests that within the general oategory of "external forces" mural connty middle-managers tend to spend the greatest amount of time dealing with community groups and organizations. Our sample of urban county middle-managers shows that they tend to spend the majority of their time dealing with administrative bodies. In addition, very few of the respondents in all three counties spent much time interacting with legislative bodies or dealing with labor and eivil service negotiations.

Program Management

The next general category was that of program managoment. TABLE XIV

PERCENT OF TDM SPEANT ON PROGRAM MANAGEMENT

$\begin{array}{lrr}\text { Multnomah } & \text { Range } & \frac{\text { Mean }}{40.7} \\ \text { Malheur } & 15-98 & 20.8 \\ \text { Jackson } & 10-25 & 22.2\end{array}$

It is worth looking more olosely at the percent of time spent in the area of program managemont, because of-a significant differonce between Multnomah Connty and the two rural counties. The greater percentage of time spent in the area of program management by Naltnomah County respondents might be attributed to the fact that they tond to specialize in the ares of program management, or that other people perform the other functions. 
TABLE XV

RANK TIME SPENT ON PROGRAM MANAGEMENT

(Relative Importance l=highest - 5-lowest)

Spootfic

Category

Program

Administration

Planning and

Development

Program

Evaluation
Multnomah

Rank Moan

1.70

1.76

2.52
Malheur

Rank Mean
Jackson

Rank Moan

The threo counties ranked the specific categories in the same order. In the general category of "Program Management" for example, program adminiatration was ranked the highest by respondents in all three countios, with planning and development and program evaluation following. Incidentally, it should be noted that even though program ovaluation was ranked last by a majority of the respondents, a number of them informaily stated that it might become more important in the future, resulting from the now omphasis on accountability.

Financial Management

The managers in 211 three of the counties spent the least amount of tipe in the ares of financial management.

\section{TABIE XVI}

PERCENT OF TTME SPENT ON FTNANCIAL MANAGEMENT

$\begin{array}{lrr}\text { Multnomah } & \text { Range } & \text { Mean } \\ \text { Malheur } & 0-40 & 14.4 \\ \text { Jackson } & 10-30 & 20.0 \\ & 5-33 & 15.5\end{array}$


In this case it is not clear to what to attribute the small percent of time sponct in the area of financial managoment. It appears that this area of manegement mast be delegated to other staff personnel. However, it is Interesting to look at the specific categories within the area of "financial management" on which respondents spent their time.

\section{TABLE XVII}

RANK TIME SPENT ON FINANCIAL MANAGEMENT

Spocific

Catogory

Financial

Administration

Financial

Planning

Revenue

Development

Financial

Evaluation
Multnomah

Rank Moan

1.86

2.00

3.00

3.07
Malhour

Rank Moan

1.66

2.33

3.00

2.75

2.4

1.75

1.75

3.00
Jackson

Rank Mean

For example,-within all threo counties, financial administration and planning wore ranked as the two areas within financial management that occupied the most time of the respondents. Interestingly, administration and planning were also the two top ranked specific eategories within the general category of "program manegement."

\section{Personnel Management}

The last category includes data regarding the porcent of tine middle-managers spent in the area of "personnel management." 


\section{TABLE XVIII}

\section{PERCENT OF TIME SPENT IN PERSONNEL MANAGEMENT}

$\begin{array}{lrr} & \text { Range } & \text { Moan } \\ \text { Multnomah } & 0-4 & 15.3 \\ \text { Malheur } & 10-45 & 23.3 \\ \text { Jackson } & 5-65 & 25.3\end{array}$

The date suggests that rural county managers spent more time in the area of personnel management than did urban managers. The rationale for this might lie in the fact that Multnomah County has its' own personnel office which takes care of personnel management.

TABLE XIX

RANK TIME SPENT IN CATEGORY OF PERSONNEL MANAGEMENT

Specific

Category

Personnel Allocation,

Task Assignment,

Needs Assessment

Staff Dovelopment

Recruitment and Selection

Affimative Action
Multnomah

Rank Mean

Malhour

Rank Moan

Jackson

Rank Mean

The specific categories were ranked in very similar order in all three counties, with the majority of the respondents ranking personnel allocation as the ares in which they spent the most time. This would include defining job duties and upgrading staff.

Malheur County managers ranked the specific categories in the same order as Nultnomah County managers. The difference in Jackson County is 80 slight as to no be significant. However, it should be noted that Noltnomah County managers probably do not spend a significant amount of time 
in the area of personnel management, unlike the rural counties, because Multnomah County managers probably have staff persons to carry out these functions. Managers in Multnomah County spend approximately twice as much time on program management as do managers in the rural counties. This might be attributed to the fact that managers in Nultnomah County seo themselves as primarily program managers, and have staff people to take care of personnel management, financial management and external forces. It can therefore be said that there exists a substantial difference between urban and mural counties in terms of the areas in which they spend their time.- For example, in the maral counties, Malherar and Jackson, the greatest amount of time was spent interacting with extermal forces, primarily community groups and administrative bodies. The internal management of the agencies was secondary to working with the external forces in these rural counties. Furthermore, in terms of the sub-categories, administration and planning came out ranking consistently high in all three counties. 
CHAPTER VI

ESSENTIAL KNOWLEDGE, PERSONAL ATTRIBUTES AND SKIHLS

The major rationale for this study was to determine specific knowledge areas, personal attributes and skills which people in management positions felt were essential to their present positions. Each interviewee was asked to look at forty-two specific items and state whether the item listed was (1) essential, (2) useful but not essential, or (3) neither essential nor useful to their present position. (See Appendix A, page 2). It should be noted that a chi-square statistical analysis was run on a number of the items listed in the "essential to present position" category. The tests showed that there no significant differences between the three counties and the way they ranked the items in terms of importance.

\section{Experience}

The first general category of items came under the broad heading of "experience." Respondents were asked to state whether experience in the areas of planning and evaluation, direct service, broad experience, management, or business experience, were essential, useful but not essential or neither useful nor essential to their present positions. 
TABLE XX

TYPE OF EXPERIENCE CONSIDERED TO BE ESSENTIAL

TO MANAGER'S PRESENT POSITIONS

$\underline{\text { Variable }}$

Planning \& Evaluation

Direct Service

Broad

Management

Business

\begin{tabular}{cc}
\multicolumn{2}{c}{ Multnomah } \\
Freq. & क \\
13 & 76 \\
12 & 70 \\
10 & 58 \\
10 & 58 \\
2 & 11
\end{tabular}

$\frac{\text { Malhour }}{\text { Freg. \& }}$

$5 \quad 83$

466

$4 \quad 66$

$4 \quad 66$

116
Frea.

$4 \quad 66$

1.16

583

350

116

As noted in Table XX, Multnomah County managers stated that they spent a large amount of their time (40\%) in the ares of program administration, which includes program planning and evaluation. Consequently. this emphasis on program administration probably accounts for the large percentage of Multnomah County managers ranking planning and ovaluation experience as essential.

As Table XX indicates, a large proportion of Malheur County managers also ranked planning and ovaluation oxporience as essestial. Furthermore, in Jackson County the majority of the managers felt that broad experience was essential to their positions. Nevertheless, their ouphasis on broad experience supports the Idea that zural county managers may tend to bo generalists more so than urban managers.

Looking at essential experiences among all three counties, there appear to be two general areas of agreement. First, planning and evaluation experience was emphasized by 22 out of 29 managers as boing essential to their present positions. Referring to the way managers spent their time, this emphasis on planning and evaluation experience is consistent with their emphasis in the amount of time spent on program planning. 
Thus, to summarize, it appears that in torms of experience felt to be essential to managers' present positions, planning and evaluation experience ranks the highest. Business experience was considered to be the least essential item of experience.

Porsonal Attributes

All interviewees were given a list ten personal attributes and were asked to state which ones they considered essential, useful but not essential, or neither useful nor essential to their present positions.

Table XXI

PERSONAL ATTRIBUTES CONSIDERED TO BE ESSENTIAL TO PRESENT POSITION

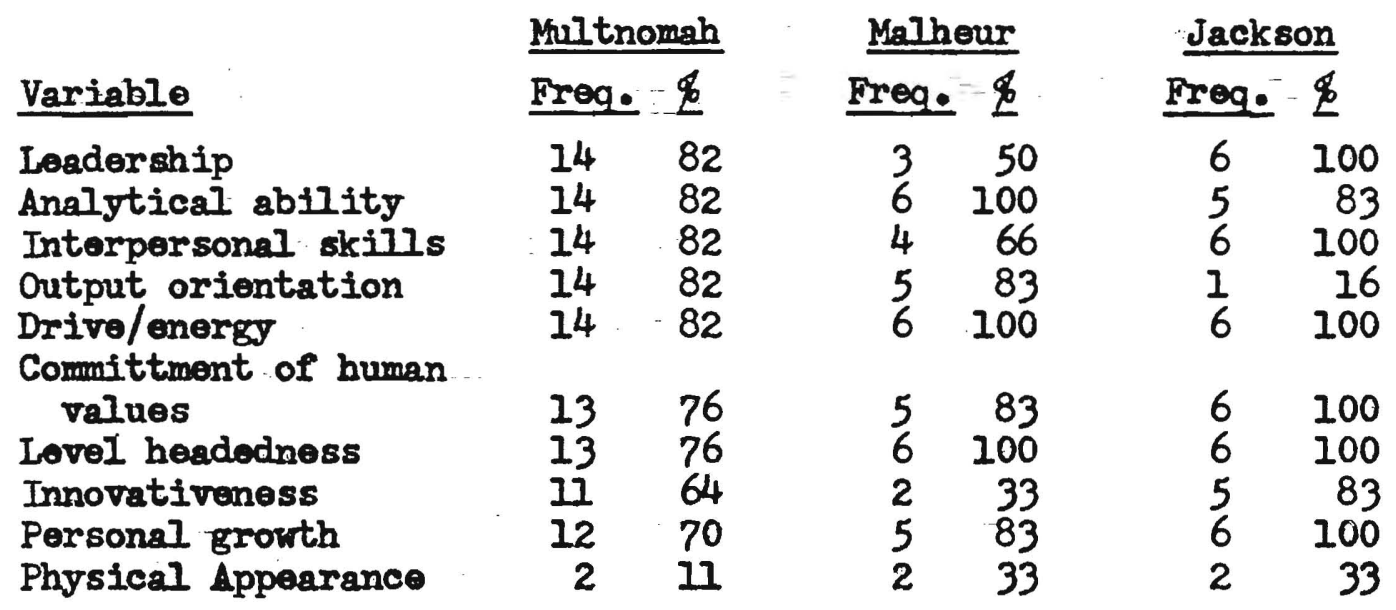

The data in the above table indicates that six of the personal attributes were Ilsted as essentiel by all-six of the Jackson County managers. In addition, innovativeness ranked higher in-Jackson County than either of the two other counties. While all of the respondents in Jackson County felt leadership to be an essential attribute, only half of the respondents. in Malheur County felt it to be essential. Furthormore, only one person in Jackson County stated that output orientation ws essential, woreas. in contrast, 82 and 83 percent of the respondents in Multnomah and Malheur 
County ranked it as essential. Thus, the most ofton rated as essential personal attributes are, starting from the highest rated: drive and energy. levelheadedness, analytical ability, a committment to human values and personal growth. Communication Skille

The managers were also asked to state which communication skills were essential to their present positions. In particular, they wore asked to respond to six separate items.

Table XXII

COMMUNICATION SKTHLS CONSIDERED $=$ TO EB-ESSEANTIAL TO PRESENT POSITION BY. MANAGERS

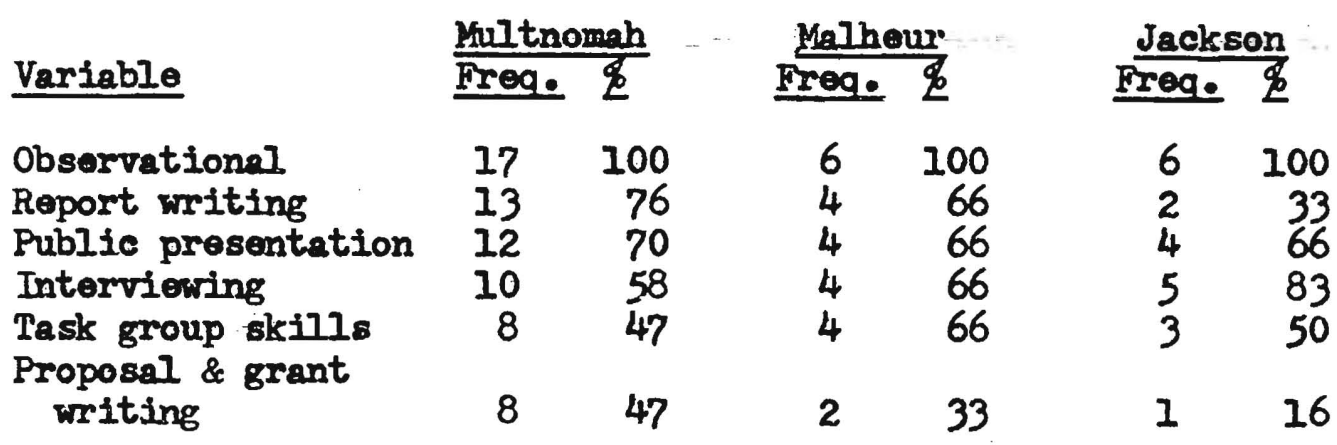

A review of the above table indicates that all 29 of the interviewees folt that observational skills were essential to their present positions. These skills Include: the abllity to pick up non-verbal expressions including what a person represents and wat his role is in a group. in addition to the ability to liston and hear for "hidden agendas" and subtle cues. Further analysis of the table reveals that managers in Malhour County ranked all of the commication skill items in a similar order to those in Nultnomah County, with only the percentages differing slightly. And finally, in Jackson County, Interviewing skills were ranked distinotly higher than in the two other counties. 
In addition, distinotive differences exist between the three counties in the area of writing skills. In Jackson County, only $33 \%$ of the people felt that roport writing was essontial, in contrast to Multnomah and Malheur County where the percentages were mich higher. And finally, proposal and grant writing, the most specific of the communication skills, ranked the lowest or least essential of the skills in all three counties. In Multnomah County $47 \%$ of the interviewees listed it as essential, $33 \%$ in Malhour_County and only $16 \%$ in Jackson County. General Knowledge Aress

All interviewees were given a list of nine general knowledge aress and were asked to state which ones were essential, useful but not essential. or neither useful nor essential to their present positions.

Table XXIII

GENERAL KNOWLEDGE AREAS CONSTDERED TO BE ESSENTIAL BY MANAGERS

Freq. $\frac{\text { Moltnomah }}{\text { Falheur }} \quad \frac{\text { Jackson }}{\text { Freq. } \underline{\phi}}$

$\begin{array}{lrrrrrr}\text { Political process } & 10 & 58 & 4 & 66 & 5 & 83 \\ \text { Organizational theory } & 10 & 58 & 3 & 50 & 3 & 50 \\ \text { Management theory } & 8 & 47 & 5 & 83 & 3 & 50 \\ \text { Social policy theory } & 7 & 41 & 1 & 16 & 2 & 33 \\ \text { Human growth \& } & 5 & 29 & 4 & 66 & 6 & 100 \\ \quad \text { developwent } & & & & & & \\ \text { Small group theory } & 5 & 29 & 4 & 66 & 2 & 33 \\ \text { Systems theory } & 5 & 29 & 0 & 0 & 2 & 33 \\ \text { Legislative process } & 3 & 17 & 3 & 50 & 3 & 50 \\ \text { Legal process } & 2 & 11 & 3 & -50 & 4 & 66\end{array}$

The table indicates that managers in Malhour County value a mixture of management knowledge and knowledge in the area of human growth and development, and small group theory. By contrast, Multnomah County managers tend to place the highest value on knowledge of the political process and organizational theory. However, it is worth noting the low percentages in Multnomah County, only two over 50\%, in the general knowledge aren 
category. It might be that the Moltnomah County respondents tend to value 8kills and personal attributes more so than general knowledge. Furthermore, Jackson County managers placed the highest value on knowledge in the area of human growth and development and the political process. Finally, this may suggest that managers in maral counties tend to value interpersonal skills more so than managers in urban countios who tend to value political and organirational skills.

Change Agent Skills

The interviewees were asked to look at a list of four change agent skills.

Table XXIV

CHANGE AGENT SKTILS CONSIDERED ESSENTIAL BY MANAGERS

\begin{tabular}{|c|c|c|c|c|c|c|}
\hline & \multicolumn{2}{|c|}{ Multnomah } & \multicolumn{2}{|c|}{ Malhour } & \multicolumn{2}{|c|}{ Jackson } \\
\hline Variable & Freg. & $\Phi$ & Freq. & $\mathscr{E}$ & Frea. & $\Phi$ \\
\hline $\begin{array}{l}\text { Resource development } \\
\text { Organizationsl }\end{array}$ & 13 & 76 & 4 & 66 & 4 & 66 \\
\hline development & 12 & 70 & 6 & 100 & 5 & 83 \\
\hline $\begin{array}{l}\text { Political Action } \\
\text { Commity }\end{array}$ & 5 & 29 & 2 & 33 & 4 & \\
\hline organization & 4 & 23 & 3 & 50 & 4 & \\
\hline
\end{tabular}

As indicated in the above table, resource development and organizational development are ranked consistently high by all three counties. This is not surprising since this is one of the jobs of management.... In addition, twice the percentage of people in Jackson County felt that political action skills were essential, in comparison to the other counties. Both Malhour and Jackson County ranked community organization skills considerably higher than did Nultnomah County. Thus, the data appears to indicate that rural managers spend more of their time out in the community than do urban managers as indicated in Table XII. Therefore, community 
organization skills tend to be emphasired more in the rural counties. Essentially, both urban and mural managers tend to be emphasizing basic and fundamental knowledge of organizations and the political process. Management Skills

Managers were asked to state which of eight management skills were ossential, useful but not essential, or neither useful nor essential to their present position.

TABLE XXV

MANAGEMENT SKTLIS CONSTDERLD ESSENTIAL TO MANAGERS

\begin{tabular}{|c|c|c|c|c|c|c|}
\hline \multirow[b]{2}{*}{ Variable } & \multicolumn{2}{|c|}{ Multnomah } & \multicolumn{2}{|c|}{ Malheur } & \multicolumn{2}{|c|}{ Jackson } \\
\hline & Freq. & 里 & Freq. & $\Phi$ & Freg. & क \\
\hline $\begin{array}{l}\text { Program planning } \\
\text { \& development }\end{array}$ & 14 & 82 & 5 & 83 & 6 & \\
\hline Crisis inanagement & 12 & 70 & 5 & 83 & 6 & 100 \\
\hline Personnel management & 11 & 70 & $\overline{6}$ & 100 & 5 & \\
\hline Program operation & 11 & 64 & 6 & 100 & 4 & \\
\hline Evaluation & 8 & 47 & 4 & 66 & 5 & 83 \\
\hline Financial management & 7 & $4 I$ & 5 & 83 & 4 & 60 \\
\hline Data uso & 4 & 23 & 3 & 50 & 2 & 33 \\
\hline Office administration & 2 & 11 & 5 & 83 & 3 & \\
\hline
\end{tabular}

The above table indicates that program planning and development skills and crisis management skills were the highest ranked skills in all three counties. Personnel management skills were also rated highly by all of the counties. Data use skills were felt to be essential by few of the respondents, $23 \%$ in Multnomah County. 33\% in Jackson County and 50\% in Melhour County. The low percentage in Nultnomah County might be attributed to the fact that a large amount of data is accumulated in some Multnomah County agencies, and therefore, data specialists are hired to do the analyses. On-contrast, there probably is less data to analyze in smaller rural counties, and therefore some of the analyses may be done by the managers themselves. Thus, looking at the listing in all threo counties of essential management skills, the following items surface: first, with in Multnomah 
County, planning and development skills are the highest ranked management skills. Secondly, within Malhour County program operation skills and personnel management skills are the highest ranked skills. And finally, in Jackson County, crisis management skills, and once again planning and development skills were ranked the highest. Therefore, the management skills that managers seem to be emphasizing are those having to do with actual program management, including program planning, development and operation.

An overall view of all six categories is necessary to understand the areas which managers feel are essential to their positions.-The six categories are: experience, personal attributes, commication skills, general knowledge, change agent skills and management skills. The data showed five items as most often listed as essential. The first one was observational skills, a communication skill which 100 percent of all interviewees listed as being essential to their position. The next was drive and energy, a personal attributerwich almost all of the respondents (94\%) Iistes as essential. Additionally, another perosnal attribute, a committment to human values, was listed as essential by 86 percent of the respondents.

It is interesting to note the discrepancy between certain management skills listed as essential, and the amount of time-spent by the respondents in these categories. For example, looking at Table XXV, under personnel management, a large percent of the respondents listed personnel management skills as essential. Howevor, looking at Table XVIII, the same respondents stated that they spent 258 or less of their time in the area of personnel management. In addition, in Table XXV, under financiel management, a large percentage of the rural county respondents stated 
that it was essential to their positions. This is in contrast to the small amount of time they said they spent in the area of financial management in Table XVI. One more personal attribute, analytical ability, was felt to be essential by 25 of the respondents (88\%). Furthermore, 25 managers (88\%), Iisted the management skills of planning and development, as essential to their present positions. 
SUMMARY STATEMENT OF ESSENTIAL ITEMS AND STTRIBUTES

Looking at the entire study, a number of items. stand out as being significant. First, in terms of specific education and training, it appears that most urban and rural managers within Oregon have had training in the areas of commication skills, change agent skills and management by objectives. They have also had training in a number of general knowledge areas, including problem solving techniques, planning theory and techniques and organizational theory.

Looking at the generalist-specialist question for both managers and staff, there appears to be some difference between the urban and in the rural counties, interviewees tend to see managers and staff as generalists.

In the area of time expenditure, there exists a distinctive. difference between urban and rural counties. For example, Multnomah County managers opend twice as mach time in the area of program management as do the rural county managers in Malheur and Jackson County. The rural managers tend to seo internal management as secondary to extermal management because they spend the majority of their time interacting with-external forces.

A number of items emerged as being essential to the respondents present positions. The highest ranked itoms were the following: observational skills, drive and energy, a committment to human values, analytical ability, and planning and dovalopment skills. 
The Ideal Menager

On the basis of this analysis, using only the frequency of responses, managers in Oregon tend to seo the ideal manager as one who:

1) Is an output oriented leader with drive and energy.

2) Fias observational skills and is analytical and level-headed.

3) Has a committment to human values and personal growth.

4) Is knowledgeable in the area of planning and development and ovaluation.

5) Is competent in the area of program management and operation.

6) Is knowledgeable about the political process and has the skills to influence that process.

7) Is compotent in communicating with both small and large groups.

8) Has an understanding of how organizations work and knows how to develop resources for programs.

9) Is competent in dealing with crises.

10) Has broad and varied experiences. 
IMPLICATIONS FOR EDUCATION OF POTENTIAL MANAGERS

The finding of this study represent the views of managers in three separate counties within the state of Oregon. These findings could be-helpful for schools attempting to train social workers, as well as others, for management positions in social service agencies. For those schools who wish to train graduates for management positions, three areas need to be examined carefully; the curriculum, field placement or-internship, and a continuing education program. Curriculum

There appears to be general consensus within the manegement literature that formal training in management has not succeeded, and many even be harmful to students. For example, Charles Handy in "Exploding the Managoment-Education Wyth," states that for students time is not a costly commodity. and student is rewarded for intellectual achievement no matter how long it takes. On the other hand, managers of programs are rewarded for being able to see an opportunity and act upon it immediately. Stanley Livingston in the "Myth of the Well-Education Manager." fools that there is no significant relationship between achievement in school and suceess in management. He points out that formal oducation overdevelops analytical ability and underdevelops the ability to take action. He suggests placing more emphasis on problem solving skills.

\section{3}

Handy, Charles. "Exploding the Management-Education Myth, "European Business, Number 29, (Spring, 1971), 79-86.

4

Iivingston, Stanley. "Myth of the Vrall-Educated Yanager," Harvard Business Review, (January-February, 1971), 78-89. 
However, he also feels that these skills can only be developed on the job. and not in the class room.

Social Work literature contains relatively few articles dealing with management education for social workers. One article by B. M. Beck, titles "Knowledge and Skills in Administration of an Anti-Poverty 5

Progra," emphasized the teaching of traditional social work skills, plus the techniques of social reform. He believes that social work education can preparo potential administrators by concentrating on "self-discipline, having a value comittment, and knowledge of the social welfare apparatus.... and ooncentrating on orasing an attitude of professionalism."

There appears to be no general agreoment on what can and what should be taught to potential managers. However, upon reviewing the list of items which make up an ideal manager, a number of items surface as being within the realm-of curriculum. For example, observational skills and group process skills could bo learned and used in an academic setting. Also planning skills, including development and evaluation, could be a part of the curriou Ium.

In view of the fact that all of the respondents felt that observational skills were essential to their positions, schools should therefore at least define and teach these skilis. The ability to observe, listen, and hear-to pick up on non-verbal expression and discovering and dealing with "hidden agendas," are skills which could be taught in a classroom.

\section{5}

Beak, B. M. "Knowledge and Skills in Administration of an AntiPoverty Program, Social Work, Volume 11, Number 3, (1971), 162-166. 
These observational skills also work in conjunction with program management skills. For examplo, students should be able to identify problems, define issues and develop specific goals. They should furthermore operationalize these goals into program activities, using real Iife situations. Moreover, they should learn to plan and conduct group meotings, an plan agendas and program content. An emphasis on a committment to human values and personal growih could also be incorporated into the curriculum.

In addition, analytic skills could bo developed in a classroom. Students could be presented with situations or problems to solve. - They could learn to specify tasks which noeded to be performod, who who perform them and to select certain procedures and resources. Ideally,- students could bring in problems and issued being dealt with in their field placemetns in order to fostor maximum participation in both settings, and to establish a communication notwork. Students should furthermore be encouraged to take courses in other divisions of the school as a means of learming specific skills not taught in their division. Therefore, an alliance should be made between the School of Sociel Work, and other departmental divisions. 


\section{Field Placement}

An examination of curriculum is not relevant without emphasizing the importance of field placement for training students to assume management responsibilities. This is consistent with Livingstone's idea mentioned earlier, that there exists no significant relationship between achievement in school and success in management. Field placement should enable a student to engage in the assistance of the actual management of an agency or a program within an agency. It is in this capacity that students demonstrate, through involvement with individuels inside and outside of the ageney, that they have, or are acquiring, the necessary knowledge and skills to achieve an acceptable- level- of professional practice.

Within this study, a number of open ended questions regarding fieldplacement, were asked of the respondents (See Appendix A, page 2). Thus, the information gathered indicated that most respondents fel that students should have experience in both single and milti-focus agencies, with the qualification that it depends upon the agency whether or not it is a valuable experience. A majority of the respondents additionally felt that an interdisciplinary setting would be good learning experience, but once again this would depend upon the agency.

A further analysis of the responses indicates that a large percentage of respondents omphasized coordinating the field placement-experience with curriculum in the school. Ideally, they felt that field experience should relate to classroom experience. - This could possibly be facilitated by increasing the communication between field supervisors and academic teachers. Furthermore, almost all interviewees emphasized that schools must become more active and involved in the community, rather than isolating themselves in an academic setting. 


\section{Continuing Education}

The schools increased involvement in the community would furthermore have implications for continuing education. For example, a number of respondents had leamed specific skills by means of continuing education classes or in-service training, both of which they felt were valuable. In addition, problem solving techniques, interviewing techniques, and management by objectives had been taught to almost all of the respondents in either continuing education classes or in service training. Continuing education courses become even more important for managers when it is realized that most managers were not specifically trained for managerial roles but were converted from an earlier specialization role. As this conversion becomes more frequent, so does the demand for management training.

All of the managers were asked if when they were in college they were aware that they would someday-be in a management position. Out of the total of 29 respondents, almost one-half (13) said, no and one-fourth (8), said yes. The remaining eight did not answer the question. This further supports the idea that most managers were converted from an earlier specialization role, and once again omphasized the noed for further training in the area of management. It is possible that prospective training programs would be better received and supported by managers if some of their colleagues were involved in the planning. Although there are generalized skills and techniques, specialists turned managers might be more effective if they had a botter understanding of the broader aspects of social satence and social policy, as well as greater skill in the art of management.*

* Multnomah County has a goneral management training program for all management staff. The State of -Oregon has management training programs provided through the Executive Department, Department of Human Resources and through divisions such as Mental Health. 


\section{BIBLIOGRAPHY}

Abels,., "The Managers are Comingl The Managers are Comingl." Public Welfare, 31 (4) (1973): 13-15.

Ansoff,H., and Brandenburg,R.G., "The General Manager of the Future," California Manasement Review, Vol.Xl, No. 3 (spring, 1969): 61-71.

Anthony, Peter, "Roles of Personnel Managers," Personnel and Training Management, (May, 1968),20-22, abstracted in Management Abstracts, Vol.8, No.3, (1968): 4.

Argento,R.C., "Behavioral Expectations as Perceived by Employing Agencies," Public Nelfare, 28 (2) (1970): 209-213.

Brager, G.A., "Advocacy and Political Beharior," Social Work, $13(2),(1968): 5-15$.

Drucker, Peter F., "Management's New Role," Harvard Business Review, (November-December, 1969): 49-54.

Griner, Larry, "What Managers Think of Participative Leadership," Harvard Business Review, (March-April, 1973): 111-117.

Handy, Charles B., "Exploding the Management Education Myth," European Business, No.29, (Spring, 1971): 79-86.

Lauffer, A., "Continuing Education as Problem-Focused Extension," Journal of Education for Social Work, 8 (3), (1972): 40-49.

Livingston, J. Sterling, "Myth of the Well-Educated Manager," Harvard Business Review, (January-February, 1971) 79-89.

Nelson, J.C., "Uses of Systems Theory in Casework 1 and 11 : A Proposal," Journal of Education for Sockäl Work, $8(3),(1972)$ $60-64$.

Revans, Reginald., "Developing Effective Managers;" Praeger Publications; New York, 1971.

Shapiro, Benson P., "Marketing for Non-Profit-organizations," Harvard Business Review, (september-october,1973): 123.

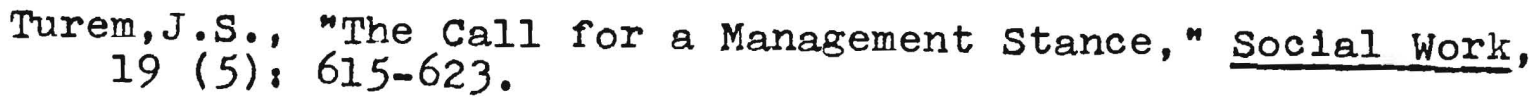

Wrapp, E.Edward, "Good Managers Don't Make Policy Decisions," Harvard Business Review, (september/october, 196?). 


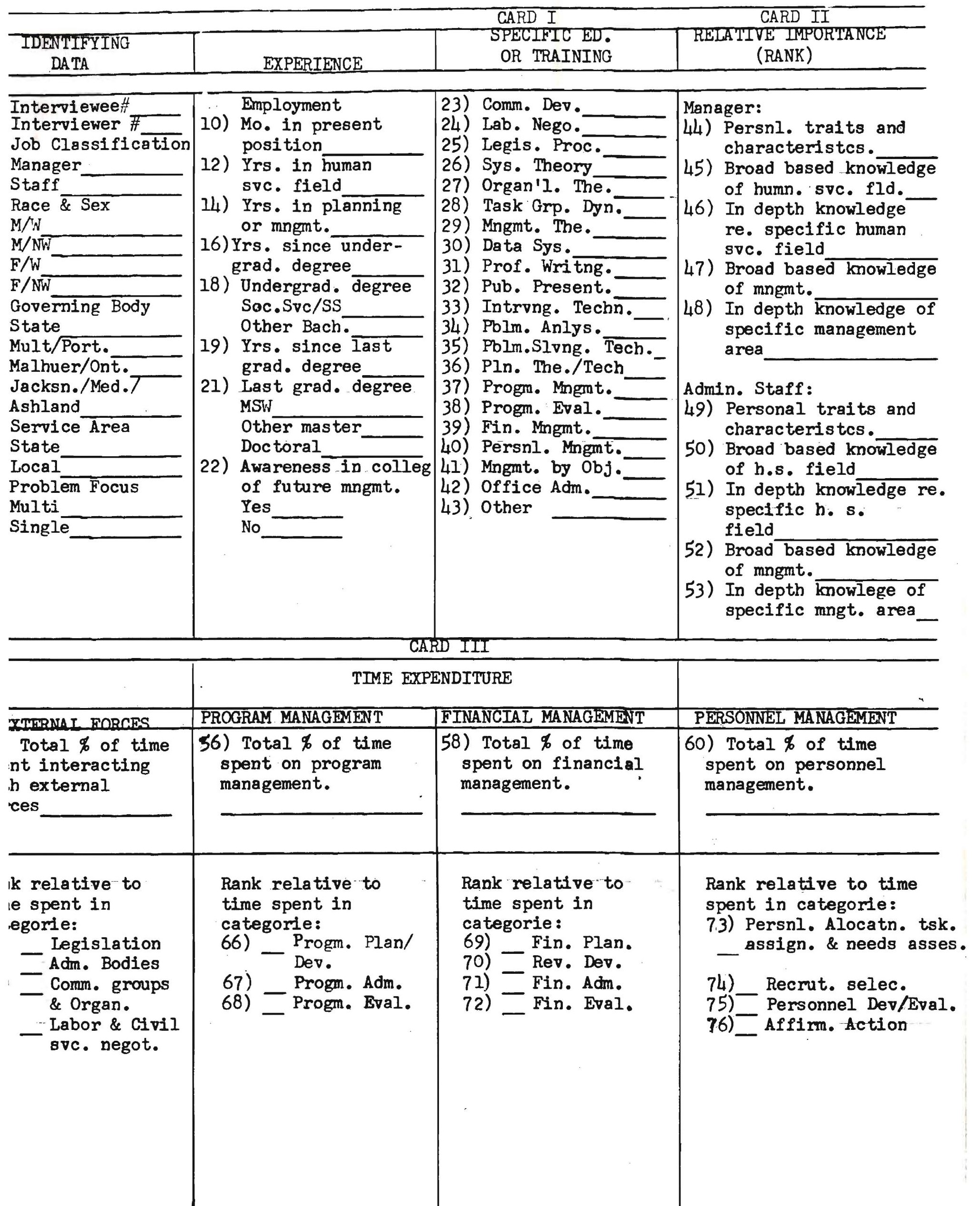


Interviewee \#

IMPORTANCE TO PRESENT POSITION

$1=$ Essential

2 = Useful but not essential

3 = Neither essential nor useful

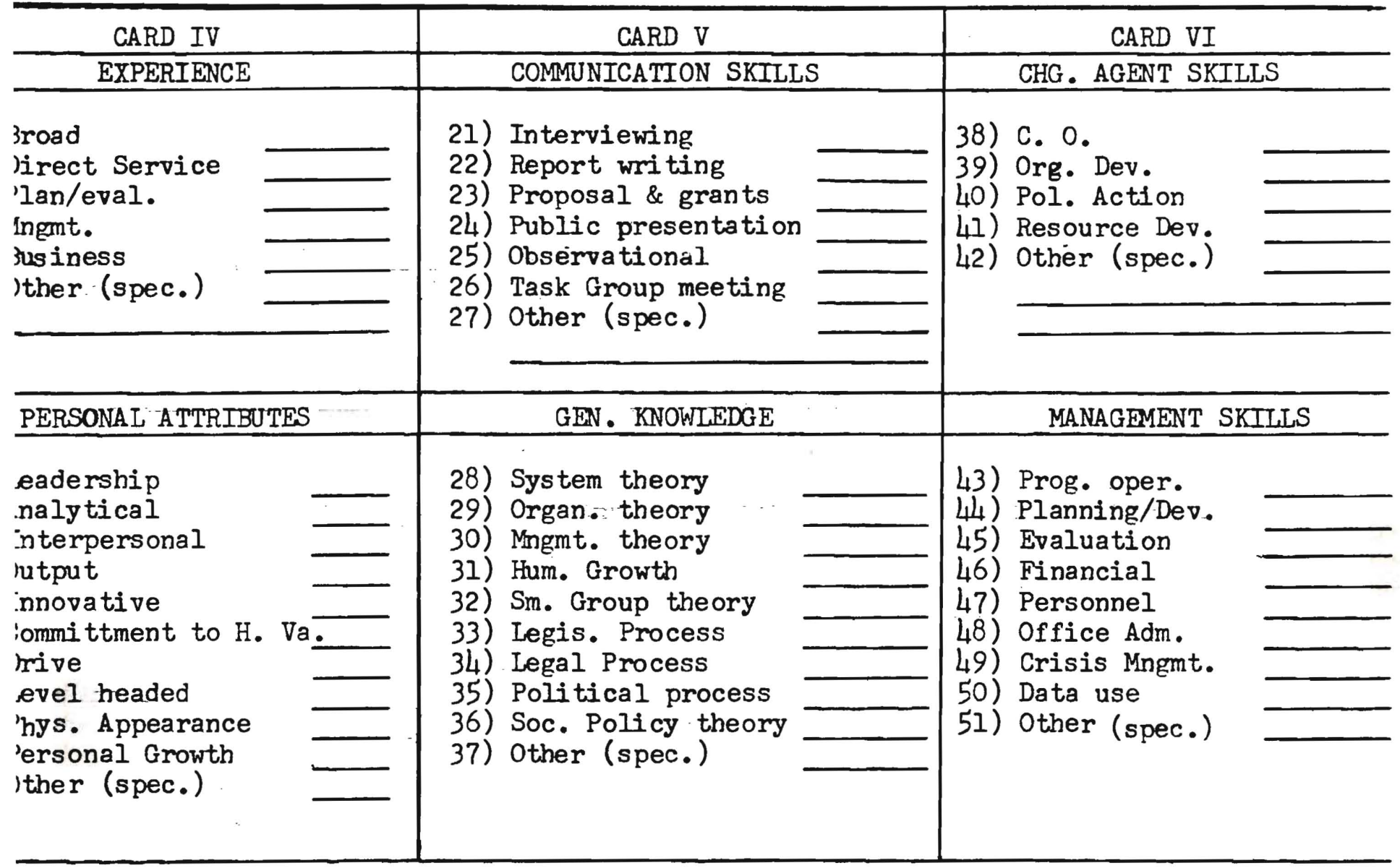

FIELD WORK FOR MSW STUDENTS

IN MANAGEMENT

1 ended questions

What recommendations do you have regarding field placements for MSW students who wish to go into management?

Probes regarding structure and experiences.

Would you be interested in having a student or students placed with you?

Probes regarding number and criteria.

Do you have any further recommendations for the school? 